\title{
PENERAPAN NILAI-NILAI KEARIFAN LOKAL TRADISI NGAROT DALAM PEMBELAJARAN SOSIOLOGI
}

\author{
Ayu Riyanti \\ Universitas Negeri Yohyakarta \\ Email: ayuriyanti@student.upi.edu
}

\begin{abstract}
Abstrak
Tradisi Ngarot merupakan tradisi yang terdapat di Desa Lelea, Kecamatan Lelea, Kabupaten Indramayu. Upacara adat Ngarot di ikuti oleh generasi-generasi muda dimana mereka diajarkan untuk bercocok tanam atau bertani. Ketika upacara adat tradisi Ngarot berlangsung banyak nilai-nilai yang arif serta pesan-pesan eksplisit yang patut di ajarkan dan dijaga eksistensinya agar kehidupan generasi selanjutnya masih tetap memegang teguh nilai dan norma terdahulu. Akibat banyak pergeseran nilai dan norma dalam masyarakat maka diperlukan pembelajaran di sekolah yang berbasis kearifan lokal khususnya dalam mata pelajaran sosiologi. penelitian ini ditulis dengan menggunakan metode observasi dan studi literatur dengan mengumpulkan data primer dari penelitian terdahulu dan terjun langsung kelapangan.
\end{abstract}

Kata kunci: $\quad$ Tradisi Ngarot, Etnopedagogi, Pembelajaran Sosiologi

\section{PENDAHULUAN}

Indonesia merupakan negara multikultural dengan beragam kebudayaan. Menurut Koentjaraningrat (2000: 180) kebudayaan adalah keseluruhan sistem gagasan, tindakan dan hasil karya manusia dalam rangka kehidupan masyarakat yang dijadikan milik diri manusia dengan belajar. Kebudayaan yang dimiliki oleh bangsa Indonesia berbeda satu sama lain. Setiap daerah memiliki corak dan keunikan masingmasing yang merupakan cerminan dari local wisdom sebuah masyarakatnnya.

Kebudayaan merupakan way of life yang dimiliki sebuah kelompok karena mengandung segala keseluruhan sistem nilai, norma, struktur sosial, bahasa dan segala sesuatu yang terdapat dalam sendi-sendi kehidupan masyarakat. Oleh karena itu kebudayaan biasanya dijadikan sebuah patokan manusia dalam bermasyarakat. Melville J.Herkovits menyatakan bahwa kebudayaan merupakan sesuatu yang bersifat super-organic, karena kebudayaan bersifat turuntemurun dari generasi kegenerasi, walaupun manusia yang ada di dalam masyarakat senantiasa silih berganti disebabkan kematian dan kelahiran (SoerjonoSoekanto: 2010: 150).

Menurut Koentjaraningrat (2000: 187) wujud ideal kebudayaan berupa ide-ide dan gagasangagasan yang hidup bersama dalam suatu masyarakat yang berkaitan dan menjadi sebuah sistem adalah adat-istiadat. Koentjaraningrat menyebutkan bahwa adat sering dijadikan undang-undang kehidupan zaman dahulu (Koentjaraningrat, 2003: 77). Hal tersebut dikarenakan adat-istiadat mengandung nilai dan norma untuk mengatur kehidupan masyarakat yang bersifat mengikat.

Nilai dan norma yang terkandung dalam kebudayaan dan adat-istiadat diimplementasikan dalam sebuah tradisi. Menurut Peursen (1976: 11) tradisi merupakan pewarisan norma-norma, kaidah-kaidah dan kebiasaan-kebiasaan. Sedangkan menurut kamus antropologi tradisi merupakan kebiasaan yang bersifat magis-religius dari kehidupan suatu penduduk asli yang meliputi nilai-nilai budaya, norma-norma, hukum dan aturan-aturan yang saling berkaitan, dan kemudian menjadi sistem budaya dari suatu kebudayaan untuk mengatur tindakan atau perbuatan manusia dalam kehidupan sosial (Ariyono dan Aminudin, 1985: 4). Adat-istiadat kerap dijadikan patokan baik dan buruk dalam kehidupan bermasyarakat. Oleh karena itu, 
sampai saat ini adat-istiadat masih dijadikan pedoman hidup sebagian masyarakat.

Dewasa ini, masyarakat dihadapkan pada tantangan pergeseran paradigma terhadap nilai sosial dan nilai budaya yang tidak dapat di hindari akibat modernisasi dan globalisasi. Huntington (1997) menyatakan bahwa istilah modern seringkali "dilawankan" dengan istilah tradisional. Globalisasi telah melahirkan nilainilai baru, gaya hidup baru dan pola interaksi sosial baru dengan segala akibatnya sebagaimana dinyatakan oleh Yuliar dan Kombaitan (2012) antara lain tajamnya kesenjangan sosial, rusaknya keharmonisan antar sesama dengan maraknya konflik antar etnis dan konflik antar pelajar, perubahan nilai dan fungsi keluarga, individualisme dan ketidakpedulian, gaya hidup materialistik dan hedonis, tipisnya rasa solidaritas dan kebersamaan, hilangnya rasa cinta produk dalam negeri, menipisnya rasa cinta dan penghargaan terhadap nilai- nilai budaya lokal sebagai bagian dari identitas kebangsaan. Arus modernisasi dan globalisasi yang sangat pesat mengakibatkan tergesernya eksistensi tradisi yang ada dalam masyarakat.

Pergeseran budaya dan kearifan lokal yang terjadi saat ini merupakan tantangan bagi pemerintah dan dunia pendidikan untuk merevitalisasi nilai-nilai yang terkandung didalamnya, karena keduanya merupakan agen perubahan sosial dalam masyarakat dan Pendidikan dianggap sebagai alternatif yang bersifat preventif untuk membentuk generasi baru bangsa yang lebih baik.Oleh karena itu institusi pendidikan memiliki peranan penting untuk mewujudkan pendidikan berbasis kearifan lokal. Kebijakan dan implementasi pendidikan yang berbasis karakter dengan mempertimbangkan berbagai nilai-nilai kearifan lokal ( local wisdom ) genius) di sekolah menjadi sangat penting dan strategis dalam rangka membangun bangsa ini. Kearifan lokal dapat berfungsi sebagai salah satu sumber nilai-nilai yang luhur bagi tujuan tersebut.

Pembentukan karakter merupakan salah satu tujuan yang ingin dicapai dalam pelaksanaan pendidikan nasional. Pada Pasal 1, UndangUndang Nomor 20 Tahun 2003 tentang Sistem Pendidikan Nasional, dinyatakan bahwa di antara tujuan pendidikan nasional adalah mengembangkan potensi peserta didik untuk memiliki kecerdasan, kepribadian dan akhlak mulia. Pendekatan etnopedagogi, merupakan salah satu alternatif baru dalam pembelajaran di sekolah yang mampu mengembangkan seluruh potensi proses pembelajaran yang lebih bermakna sekaligus menjadi salah satu upaya pemecahan persoalan dalam masyarakat.

Tantangan pergeseran paradigma terhadap nilai sosial dan nilai budaya akibat modernisasi juga dirasakan oleh masyarakat Indramayu. Di tengah-tengah arus modernisasi dan budaya global yang berkembang pesat, terdapat beberapa kearifan lokal yang yang sudah diwariskan secara turun-temurun dari generasi ke generasi. Saat ini banyak tradisi yang terancam punah, oleh karena itu dalam melestarikan sebuah tradisi diperlukan upaya khusus agar kearifan-kearifan yang terkandung dalam tradisi tersebut dapat diinternalisasikan oleh masyarakatnya meskipun nilai dan norma masyarakat zaman dahulu dan saat ini mengalami perubahan.

\section{TINJAUAN PUSTAKA 2.1. Kearifan Lokal}

Kearifan lokal atau local wisdom dikenal juga dengan istilah local genius. Local genius ini merupakan istilah yang dikenalkan oleh Quaritch Wales. kearifan lokal menurut Haryati Soebadio merupakan identitas budaya atau cultural identity bangsa yang menjadikan bangsa tersebut mampu menyerap dan mengolah kebudayaan asing sesuai watak dan kemampuan sendiri (Ayatrohaedi, 1986:18-19). Sedangkan definisi kearifan lokal menurut Keraf (2002) yaitu semua bentuk pengetahuan, keyakinan, pemahaman atau wawasan serta adat kebiasaan atau etika yang menuntun perilaku manusia dalam kehidupan di dalam komunitas ekologis. Definisi tersebut memberikan perspektif bahwa manusia sebagai makhluk integral yang selalu ingin bersatu dengan lingkungan alam dan lingkungan sosialnya serta bertanggung jawab untuk dapat hidup secara seimbang dengan memelihara alam dan memelihara hubungan sesama manusia. Oleh karena itu diperlukan nilai dan norma untuk menjaga keutuhan dan keseimbangan alam dan sosial tersebut. Selain itu menurut Sibarani (2012: 112-113) dijelaskan bahwa pada hakekatnya kearifan lokal adalah kebijaksanaan atau pengetahuan asli suatu masyarakat yang berasal dari nilai luhur tradisi budaya untuk mengatur tatanan kehidupan masyarakat. Kearifan lokal biasanya selalu dijadikan patokan masyarakat dalam bertindak dan berperilaku sehingga Kearifan lokal sering dijadikan alat untuk mengatur tatanan kehidupan bermasyarakat. Kearifan lokal merupakan produk budaya masa lalu yang patut dijadikan pegangan hidup. Nilainilai dalam kearifan lokal dianggap universal dan mampu mengatur secara efektif perilaku masyarakat. Nilai-nilai yang diyakini kebenarannya tersebut menjadi acuan masyarakat dalam berperilaku. Oleh karena itu kearifan lokal sering dianggap sebagai wujud kehormatan, harkat dan martabat sebuah kelompok masyarakat secara eksplisit. 
Nilai-nilai dalam kerarifan lokal yang terdapat dalam sistem sosial masyarakat diharapkan untuk dapat dimaknai secara mendalam kemudian di implementasikan dalam kehidupan masyarakat agar nilai tersebut dapat diajarkan kepada generasi penerus agar membentuk dan menuntun pola perilaku manusia dalam kehidupan seharihari baik terhadap lingkungan alam maupun lingkungan sosialnya. Nababan (2003) menyebutkan bahwa masyarakat adat yang masih bersifat tradisional yang masih memiliki ikatan sosio-kultural serta religi yang erat pada umumnya memiliki sistem pengetahuan dan pengelolaan kearifan lokal yang diwariskan dan dipelihara secara turun temurun agar kearifan tersebut mampu bertahan eksistensinya. Karena pada hakikatnya nilai-nilai yang terkandung dalam kearifan lokal mengarahkan manusia untuk selalu berperilaku secara baik dan arif.

\subsection{Tradisi Ngarot \\ 2.2.1. Proses dan Pelaksanaan Tradisi Ngarot}

Ngarot merupakan tradisi yang dimiliki oleh Desa Lelea, Kecamatan Lelea, Kabupaten Indramayu, Provinsi Jawa Barat yang diwariskan oleh sesepuh Desa Lelea yaitu Ki Buyut Kapol. Ngarot selalu dilaksanakan untuk mengawali musim tanam di sawah yang akan digarap oleh para Kasinoman (muda-mudi) ketika musim penghujan datang antara bula oktober sampai dengan bulan desember Waktu pelaksanaan upacara adat Ngarot secara turun temurun jatuh pada hari Rabu Wekasan yaitu antara bulan Oktober dan November setiap tahunnnya. Upacara adat Ngarot melibatkan berbagai pihak dalam pelaksanannya seperti pemuda-pemudi, kepala desa beserta istri, para wakil lembaga desa, dan juga para seniman. Selain itu upacara Ngarot juga di iringi berbagai bentuk kesenian tradisional seperti kesenian tari topeng, tari ronggeng ketuk, alat musik tanjidor, reog serta sampyong.

Syarat untuk mengikuti upacara adat Ngarot adalah pemuda dan pemudi yang masih menjaga kesuciannya dan belum menikah yaitu yang masih perawan dan perjaka. Pakaian yang dikenakan saat upacara berlangsung sangat unik, sang bujang mengenakan baju komboran hitam dan celana pangsit dan ikat kepala sidamukti, sedangkan sang cuwene mengenakan baju kurung yang saat ini diganti dengan mengenakan kebaya, selendang juwana dan perhiasan emas. Sedangkan sebagai tutup kepala dihiasi dengan berbagai jenis bunga-bungaan seperti kenanga, melati, cempaka, karniyem pudak dan kembang yang dibuat dari bahan kertas.Ibu Kuwu sebagai Ratu dalam upacara adat Ngarot mengenakan kebaya, kain batik trusmi (batik buatan Indramayu), selendang, topi buatan Majalaya, dan juga perhiasan emas.Sedangkan para pamong desa mengenakan pakaian batik, beserta istri pamong desa berpakaian seragam baju kebaya, kain batik dan selendang. Masyarakat Desa Lelea mempercayai mitos bahwa hanya yang masih suci yang dapat mengikuti upacara adat Ngarot, karena jika ada Cuwene yang sudah tidak suci maka bunga sebagai hiasan dikepalanya akan layu dan ketika upacara berlangsung akan terlihat buruk rupa dimata orang lain.

\subsubsection{Persiapan Pelaksanaan}

Sebelum mengadakan upacara adat Ngarot banyak hal yang harus dipersiapkan salah satunya adalah menetapkan tanggal dilaksanakannnya upacara tersebut. Kepala Desa/KuwuLelea sebagai pemimpin desa sekaligus pemimpin dalam upacara adat Ngarot sedikitnya melakukan musyawarah sebanyak dua kali.Musyawarah yang dilakukan oleh Kuwu dalam mempersiapkan tradisi Ngarot adalah sebagai berikut.

a. Musyawarah yang pertama Kuwu melibatkan para pamong desa, Lembaga desa Lelea seperti LMD (Lembaga Masyarakat Desa), LKMD (Lembaga Keamanan Masyarakat Desa), PPK serta tokoh masyarakat dan karang taruna untuk menetapkan waktu, hari, dan tanggal pelaksanaan upacara adat Ngarot. Setelah mendapat keputusan dari hasil musyawarah mengenai waktu yang tepat untuk melaksanakan upacara adat Ngarot, $\mathrm{Kuwu} /$ kepala desa mengumumkan waktu pelaksanaan upacara Ngarot kepada seluruh Masyarakat Desa Lelea ketika upacara sedekah bumi berlangsung.

b. Musyawarah yang kedua melibatkan pemuda-pemudi peserta upacara adat Ngarot untuk menentukan warna pakaian yang akan dikenakan pada saat upacara adat Ngarot berlangsung. Penentuan warna tersebut dikhususkan untuk para Cuwene yang akan mengikuti upacara Ngarot yaitu penentuan warna baju kebaya dan selendang juwana, sedangkan sang bujang tetap mengenakan baju komboran warna hitam dan celana pangsit serta ikat kepala sidamukti.

\subsubsection{Pelaksanaan Tradisi Ngarot}

Upacara adat Ngarot secara turun temurun dilaksanakan pada hari rabu wekasan yaitu antara bulan Oktober dan November. Hari Rabu merupakan hari yang mutlak untuk melaksanakan upacara adat ngarot, pemilihan hari rabu yang mutlak hal dilatarbelakangi oleh kepercayaan masyarakat Lelea yang mempercayai apabila 
tidak dilaksanakan pada hari Rabu maka akan datang bala bencana. Ketika tiba dihari pelaksanaan tradisi Ngarot bujang dan cuwene mempersiapkan pakaiannya dari pagi buta, yaitu sekitar pukul 04.00-06.00 WIB. Persiapan dari pagi buta biasanya dilakukan oleh para cuwene, hal ini dikarenakan sebelum upacara adat Ngarot dimulai para cuwene harus di make over atau dirias terlebih dahulu. Selain di make over para cuwene juga dihiasi bunga-bunga pada kepalanya yang biasanya dilakukan oleh orang yang memiliki kemampuan secara magis dalam memasang cunduk bunga di kapala cuwene. Dalam merias wajah dan kepala biasanya antre sehingga pagi-pagi buta para cuwene harus segera bergegas ketempat make over. Ketika rias muka dan kepala selesai para gadis dihiasi oleh perhiasan emas, perhiasan tersebut bertujuan untuk menunjukan dari keluarga mana ia berasal dan menunjukan kekayaan orang tua dan keluarganya.

Setelah persiapan pakaian dan tata rias telah selesai bujang dan cuwene peserta upacara adat Ngarot dari masing-masing blok dikawal menuju rumah Kuwu/Kepala Desa oleh masing-masing kepala dusunnya. Setelah semua peserta upacara adat Ngarot berkumpul di rumah Kuwu tepat pukul 09.00 WIB para peserta upacara Ngarot diajak untuk pawai berkeliling desa sampai ke perbatasan desa yaitu Desa Tamansari. Dalam pawai mengelilingi Desa Lelea terdapat aturan susunan peserta pawai yang telah ditetapkan oleh pelaksana upacara Ngarot sejak dahulu, adapun susunan peserta pawai tradisi Ngarot tersebut adalah barisan paling depan di isi oleh bapak Kuwu beserta ibu Kuwu/istri Kuwu (kepala desa) juga Camat kemudian diikuti oleh istri pamong Desa Lelea dan diikuti oleh para cuwene yang telah berpakaian kebaya lengkap dengan hiasan bunga dikepalanya serta di bagian belakang di iringi oleh alat musik tanjidor. Tepat dibarisan belakang para pemain musik tanjidor disusul oleh para bujang yang mengenakan baju komboran dan celana pangsit serta kain untuk pengikat kepala kemudian disusul oleh iring-iringan pamong desa laki-laki yang diiringi oleh kesenian reog, dibelakang para pemain reog disusul oleh lembaga-lembaga yang ada di Desa Lelea yang kemudian diiringi oleh kesenian genjring (rebana) sedangkan barisan paling belakang biasanya diisi oleh masyarakat atau keluarga dari peserta upacara adat Ngarot yang ingin mengikuti pawai mengelilingi Desa Lelea.

Saat pawai berlangsung masyarakat Desa Lelea telah bersiap di sepanjang jalan untuk menonton iring-iringan sehingga suasana pawai tersebut berjalan dengan meriah dan suka cita.Pawai tradisi Ngarot mengelilingi Desa Lelea berakhir di Balai Desa Lelea.Ketika memasuki balai desa, Kuwu beserta istri disambut oleh penabuh gamelan dengan membawakan lagu Jipang Keraton sebagai bentuk penghormatan kepada Raja dan Ratu dalam upacara Adat Ngarot yang dalam hal ini adalah Bapak dan Ibu Kuwu.Ketika Kuwu beserta istri berjalan memasuki paseban sebagai bentuk penghormatan Kuwu beserta istri ditaburi dengan beras yang berwarna kuning.

Setelah pawai mengelilingi Desa Lelea, acara puncak upacara adat Ngarot dimulai. Pertamatama seluruh penonton dan peserta upacara Adat Ngarot dikondisikan oleh panitia.Para bujang dan cuwene duduk berhadap-hadapan hal tersebut bertujuan agar bujang dan cuwene dapat saling memandang. Setelah situasi telah kondusif maka acara inti upacara adat Ngarot pun dimulai dengan susunan acara sebagai berikut.

a. Pembukaan oleh panitia

Pembacaan petuah kekolot Lelea sebagai berikut.

1. Mikirun budak kena kumaa (memikirkan anak nantinya bagaimana)

2. Kajen boga harta kudu tetep usaha (walaupun mempunyai harta harus tetap usaha)

3. Kur ngora ulah poya-poya (ketika muda jangan berfoya-foya)

4. Kamberan kolot ulah sengsara (agar dimasa tua tidak sengsara)

5. Jelma laki kerja ewena usaha (laki-laki bekerja, perempuannya usaha)

6. Neangan pekaya rukun runtut (mencari kekayaan bersama-sama)

7. Aturan agama kudu diturut (aturan agama harus dilaksanakan)

8. Selamat dunia jung akheratna (selamat di dunia dan di akheratnya)

b. Pembacaan sejarah singkat tradisi Ngarot

c. Sambutan Kuwu Lelea

d. Prosesi penyerahan seperangkat alat pertanian secara simbolis oleh kuwu dan pamong desa kepada perwakilan bujang dan cuwene yang telah di tunjuk.

Adapun proses penyerahannya adalah sebagai berikut.

a. Penyerahan benih padi oleh Kuwu (kepala desa) kepada peserta Ngarot lakilaki/bujang. Maksud dari penyerahan benih padi adalah agar bibit padi tersebut ditanam oleh para bujang supaya mendapat hasil panen yang melimpah.

b. Penyerahan kendi berisi air putih oleh istri Kuwu(kepala desa) kepada peserta Ngarot perempuan/cuwene. Maksud dari penyerahan kendi berisi air putih adalah agar benih padi yang telah ditanam tidak pernah kekurangan air serta sebagai air obat 
penyubur tanah sehingga padi yang di tanam memiliki hasil yang melimpah.

c. Penyerahan alat pertanian berupa cangkul dan pedang oleh Raksa Bumi (pamong pengurus sawah dan tanah desa) kepada peserta Ngarot laki-laki /bujang. Maksud dari penyerahan cangkul dan pedang adalah agar menyuburkan tanaman padi.

d. Penyerahan pupuk oleh tokoh masyarakat (tetua) Desa Lelea kepada peserta Ngarot Laki-laki/bujang. Maksud dari penyerahan pupuk adalah agar pupuk tersebut disebar di sawah ketika menggarap sawah supaya menyuburkan tanaman padi.

e. Penyerahan ruas bambu kuning, daun andong, daun kelaras dan daun pisang klutuk wuluh oleh Lebe (pamong pengurus pernikahan) kepada peserta Ngarot laki-laki / bujang . maksud dari penyerahan dedaunan tersebut adalah agar dedaunan tersebut ditancapkan di tengah-tengah persawahan supaya tanaman padi terhindar dari hama dan penyakit.

Setelah melewati acara penyerahan berbagai keperluan bertani secara simbolik seperti yang telah dijelaskan di atas, acara selanjutnya yaitu peresmian acara pesta Ngarot dengan ditandai oleh pemukulan gong oleh Kuwu Lelea sebagai pemangku upacara adat Ngarot. Pesta upacara Ngarot Desa Lelea resmi di mulai dan hiburan-hiburan yang sudah disediakan pun segera ditampilkan. Para cuwene biasanya menyaksikan kesenian tari topeng sebagai hiburan, sedangkan para bujang telah disediakan hiburan kesenian ronggeng ketuk dan tanjidor, para bujang yang mengikuti Ngarot dipersilahkan untuk menari ronggeng bersama penari ronggeng secara bergiliran dengan catatan harus menyediakan uang terlebih dahulu untuk membayar sang penari ronggeng. Upacara adat Ngarot pada siang hari selesai Pada pukul 12.00 WIB yang kemudian dilanjutkan kembali pada malam hari.

Pada pukul 19.30 WIB peserta Ngarot berkumpul kembali di kediaman Bapak Kuwu Lelea dengan formasi yang sama yaitu dipimpin oleh kepala dusun masing-masing blok. Setelah berkumpul seluruh peserta Ngarot melakukan pawai kembali namun dengan rute yang lebih pendek yaitu hanya dari kediaman Kuwu menuju Balai Desa dengan diiringi musik tanjidor.Ketika memasuki balai desa mereka disambut oleh alunan gamelan yang memainkan lagu jipang keraton persis seperti penyambutan pada pagi hari.Hiburan yang telah disediakan tersebut berlangsung semalaman ketika pesta Ngarot berlangsung.

\section{METODE}

Penelitian ini menggunakan metode penelitian kualitatif yang bersifat deskriptif. Teknik pengumpulan data yang dipakai adalah observasi dan studi literatur.

\section{HASIL DAN PEMBAHASAN 4.1. Tradisi Ngarot Sebagai Wujud Kearifan Lokal Masyarakat Desa Lelea Indramayu}

Eksistensi tradisi merupakan keberadaan tradisi yang bukan hanya sekedar ada tetapi diakui dan tetap dilaksanakan secara kontinyu. Dalam masyarakat desa Lelea tradisi Ngarot sudah ada keberadaannya sejak 500 tahun yang lalu ketika Ki Buyut Kapol menjabat menjadi Kepala Desa (Kuwu) di Desa Lelea. Eksistensi dalam tradisi Ngarot tidak terlepas dari antusias masyarakatnya dalam menyambut dan melaksanakan tradisi Ngarot sehingga sampai saat ini tradisi Ngarot tetap bertahan dan diakui oleh masyarakat luas. Masyarakat Desa Lelea sangat mendukung agar tradisi Ngarot dapat terlaksana secara berkesinambungan.

Dalam tradisi ngarot terdapat nilai-nilai arif yang terkandung yang dapat diajarkan dalam dunia pendidikan. Seperti pembelajaran untuk bercocok tanam bagi remaja, ditengah-tengah modernisasi dan sistem pendidikan yang sudah maju remaja saat ini enggan untuk bekerja sebagai petani dan lebih memilih untuk bekerja di sektor industri. Remaja harus diajarkan bertani sejak dini untuk merevitalisasi para petani yang sudah memasuki usia lanjut agar kearifankearifan dalam bertani tetap terjaga. Selain itu tradisi ngarot mengajarkan agar remaja menghindari pergaulan bebas yang sedang marak terjadi di kalangan remaja dikarenakan perempuan yang sudah tidak suci akan terlihat buruk rupa pada saat prosesi upacara ngarot berlangsung.

Mitos yang dipercaya Masyarakat Desa Lelea adalah jika tradisi Ngarot tidak dilaksanakan pada hari rabu wekasan maka akan terjadi huru-hara di Desa Lelea oleh karena itu tradisi Ngarot selalu dilaksanakan setiap tahunnya. Tradisi Ngarot ini belum pernah sekalipun tidak dilaksanakan oleh masyarakat desa Lelea sejak tahun 1646. Peran pemuda dan pemudi di Desa Lelea juga merupakan faktor penting terhadap eksistensi tradisi Ngarot. Meskipun tradisi Ngarot merupakan tradisi yang sudah ada sejak beberapa abad yang lalu namun pemuda-pemudi Desa Lelea tidak pernah menganggap tradisi Ngarot 
sebagai sesuatu yang kuno bahkan mereka merasa bangga dengan adanya tradisi Ngarot yang belum tentu dimiliki oleh desa lain. Meskipun dihadapkan pada perubahan sosial dan modernisasi kesakralan dalam tradisi Ngarot masih bisa dirasakan terutama pada saat penentuan tanggal untuk melaksanakan upacara adat Ngarot. Dalam tradisi Ngarot diperlukan tiga hiburan untuk mengiringi keberlangsungan upacara adat Ngarot yaitu kesenian tari topeng, tari ronggeng ketuk, dan tanjidor. Hiburanhiburan tersebut tetap eksis digunakan dalam pelaksanaan tradisi Ngarot sejak zaman Ki Buyut Kapol memimpin.

Perubahan sosial dan perubahan budaya dalam masyarakat adalah dua proses yang saling berkaitan satu sama lain, karena tidak ada masyarakat yang tidak memiliki budaya, begitupun sebaliknya tidak mungkin tercipta kebudayaan tanpa adanya masyarakat. Mengingat sifat masyarakat yang dinamis dan dapat berubah kapan saja, tidak menuntut kemungkinan kebudayaan yang terdapat dalam masyarakatpun ikut berubah. Tradisi Ngarot di Desa Lelea dalam perkembangannya sedikit mengalami perubahan terutama keadaan para peserta upacara adatnya. Selain perbedaan usia terdapat juga komponen penting dalam tradisi Ngarot yang mengalami perubahan yaitu kegiatan durugan. Durugan merupakan kegiatan mengolah sawah warisan $\mathrm{Ki}$ Buyut kapol yang dilakukan oleh kasinoman atau peserta upacara adat Ngarot.Meskipun terdapat beberapa perbedaan dan perubahan dalam eksistensi tradisi Ngarot, kesakralan yang ada dalam tradisi Ngarot masih tetap terjaga karena acara inti dalam upacara adat Ngarot masih dilaksanakan sampai saat ini sehingga tradisi Ngarot tetap terjaga eksistensinya.

\subsection{Revitalisasi agar tradisi Ngarot tetap eksis}

Pelestarian tradisi memerlukan keterlibatan dan partisipasi dari berbagai komponen antara lain masyarakat setempat, lembaga swadaya masyarakat, para akademisi dan pemerhati budayaserta pemerintah daerah setempat yang menjabat. Partisipasi berarti peran serta seseorang atau kelompok masyarakat dalam proses pembangunan baik dalam bentuk pernyataan maupun dalam bentuk kegiatan dengan memberi masukan pikiran, tenaga, waktu, keahlian,modal dan atau materi, serta ikut memanfaatkan dan menikmati hasil-hasil pembangunan (dalam Sumaryadi, 2010: 46). Partisipasi masyarakat dan pemerintah daerah dalam upaya pelestarian tradisi merupakan suatu prioritas karena masyarakat setempat dan pemerintah daerah adalah pewaris asli dari sebuah tradisi yang tidak dimiliki oleh daerah yang lain, oleh karena itu partisipasi dan kerjasama dari semua komponen sangat diperlukan dalam menjaga dan melestarikan sebuah tradisi. Begitu juga dalam upaya pelestarian tradisi Ngarot pada masyarakat Desa Lelea diperlukan adanya kerjasama dari berbagai pihak.

Untuk menjaga kelestarian Ngarot pemerintah daerah bekerjasama dengan masyarakat setempat agar tradisi Ngarot tetap terjaga eksistensinya. Upaya dalam melestarian tradisi Ngarot tidak hanya semata-mata menjadi kewajiban masyarakat Desa Lelea saja oleh karena itu pemerintah daerah juga bekerjasama dengan pemerintah tingkat kabupaten dan tingkat provinsi. Partisipasi dan kerjasama yang dilakukan oleh masyarakat,pemerintah dan komponen lainnya memberikan ruang terhadap tradisi Ngarot untuk terus berkembang dari generasi ke generasi.

Modernisasi yang terjadi dewasa ini memberikan dampak signifikan terhadap generasi muda. Modernisasi mengakibatkan pola pikir generasi muda tidak lagi bisa dibatasi. Tidak dapat dipungkiri bahwa saat ini budaya global lebih banyak digemari remaja dibandingkan dengan budaya lokal / budaya tradisional oleh karena itu diperlukan usaha untuk memotivasi remaja agar mencintai budaya lokal yang dimiliki daerahnya.Untuk itu pemerintah daerah Desa Lelea mempunyai cara khusus untuk menanggulangi rendahnya minat remaja dalam berpartisipasi terhadap kebudayaan lokal secara langsung, pemerintah daerah memberikan reward untuk para peserta berupa uang Rp.100.000,00 bagi yang mengikuti acara durugan dan pembagian kupon undian bagi peserta yang mengikuti tradisi Ngarot sampai pada penutupan acara. Sistem pemberian reward terhadap peserta Ngarot dilakukan oleh pemerintah Desa Lelea sebagai salah satu cara untuk memotivasi para peserta tradisi Ngarot untuk mau mengikuti tradisi Ngarot. Pemberian reward terhadap peserta Ngarot tidak hanya diberikan oleh pemerintah daerah melainkan diberikan juga oleh orang tua, tetangga dan saudara-saudara peserta Ngarot.

Berdasarkan penjelasan diatas membuktikan bahwa sistem reward ini sangat membantu dalam upaya pelestarian tradisi Ngarot meskipun memang orientasi peserta lebih kepada agar mendapat banyak uang namun para peserta setidaknya memiliki motivasi untuk mengikuti tradisi Ngarot sehingga tradisi Ngarot tetap terjaga eksistensinya.

Pemerintah Desa Lelea telah mengupayakan banyak hal dalam upaya pelestarian tradisi Ngarot agar terjaga eksistensinya, salah satunya yaitu dengan mencanangkan kampung adat di Desa Lelea. Kampung adat tersebut dibentuk agar 
masyarakat Desa Lelea khususnya dapat mengetahui bagaimana prosesi tradisi Ngarot pada zaman Ki Buyut Kapol menjabat. Rencana pembangunan kampung adat di Desa Lelea ini telah disampaikan oleh pemerintah daerah kepada pemerintah kabupaten dan provinsi. Didirikannya kampung adat di desa Lelea ini merupakan bentuk upaya yang dilakukan oleh pemerintah daerah agar tradisi Ngarot selalu terjaga eksistensinya, selain itu untuk mengenalkan kepada masyarakat luas bagaimana prosesi tradisi Ngarot ini karena jika tradisi Ngarot ini telah diketahui masyarakat luas maka akan membantu proses pelestarian tradisi Ngarot.

\subsection{Implementasi etnopedagogik dalam pembelajaran sosiologi sebagai upaya merevitalisasi nilai-nilai kearifan lokal} pembudayaan nilai-nilai budaya dan kearifan lokal pada masyarakat yang meyakini dan memegang prinsip-prinsip yang sudah terinternalisasi secara turun temurun. Dalam pendidikan terdapat proses pembelajaran baik itu pembelajaran nilai-nilai maupun pembelajaran untuk menambah pengetahuan, adanya kearifan lokal dalam masyarakat yang memiliki nilai-nilai baik didalamnya perlu untuk diajarkan kepada generasi muda sedini mungkin agar masyarakat memiliki tatanan perilaku yang baik terhadap alam dan lingkungan sosial serta eksistensinya terjaga. Oleh karena itu pendekatan pembelajaran di sekolah berbasis kearifan lokal atau etnopedagogi menjadi salah satu alternatif baru dalam mengembangan model pembelajaran dengan tujuan mengenalkan nilai-nilai kearifan lokal dalam budaya kepada generasi muda khususnya para pelajar.

Alwasilah memandang Etnopedagogi sebagai praktik pendidikan berbasis kearifan lokal sebagai sumber inovasi dan ketrampilan dalam proses pembelajaran (2009). Khusainov and Galimov (2014) menyebutkan " ethno-pedagogy is thegeneralize concept meaning the comparative analysis of educator traditions of differentpeople. People are an only and inexhaustible source of spriritual values".

Etnopedagogi merupakan pembelajaran berbasis nilai-nilai budaya kearifan lokal. Melalui pendekatan etnopedagogi, guru di sekolah dapat mengambil setting/tema budaya tertentu sebagai sumber belajar untuk disampaikan kepada siswa. Etnopedagogi memandang pengetahuan atau kearifan lokal sebagai sumber inovasi dan keterampilan yang dapat diberdayakan demi kesejahteraan masyarakat (Alwasilah, 2008 dalam Nurul Zuriah, 2014). Anwar Hafid juga menjelaskan bahwa "...Ethnopedagogy is an educationalpractice based on local wisdom in various fields such as medicinal treatment, self defence art, living environment, agriculture, economy, government, calendar system, andetc. Ethnopedagogy perceives that knowledge or local wisdom as the source of innovationand skill that can be empowered for the sake of the society's welfare...". Pendapat ini semakin menegaskan bahwa etnopedagogi mengangkat nilai-nilai kearifan lokal sebagai bagian penting dalam proses pendidikan karena bagian dari proses pembudayaan atau pembiasaan nilai-nilai kearifan lokal yang ada. Selain itu perubahan sosial yang sangat dinamis sering memicu timbulnya konflik juga menempatkan etnopedagogi sebagai model pembelajaran untuk mengatasi berbagai perbedaan-perbedaan dalam masyarakat.

Pembelajaran melalui pendekatan etnopedagogi melihat pengetahuan lokal sebagai sumber inovasi dan keterampilan yang dapat diberdayakan (Priadi Surya, 2011) untuk proses pembelajaran yang sedang dan akan berlangsung. Kearifan lokal merupakan ungkapan budaya yang khas, didalamnya terkandung tata nilai, etika, norma, aturan dan ketrampilan suatu komunitas dalam memenuhi tantangan keberlanjutan kehidupannya (Suswandari, 2017). Tidak jarang kearifan lokal sering digunakan sebagai lokal decisión making, sebagaimana berlaku dalam bidang pengelolaan sumber daya alam dan berbagai aktivitas sosial lainnya dalam lingkungan kehidupan masyarakat.

Pendidikan berbasis kearifan lokal atau etnopedagogik dapat di implementasikan dalam mata pelajaran sosiologi dengan menyelipkan nilai- nilai kearifan lokal sebagai sumber belajar. Implementasi pendekatan etnopedagogi dalam pembelajaran sosiologi di sekolah menjadi salah satu upaya pemecahan persoalan-persoalan yang ada pada masyarakat. siswa diajak untuk peka terhadap lingkungan sosialnya. Siswa diajak untuk mencari tahu apa saja kearifan lokal yang ada pada daerahnya masing-masing. Karena pada dasarnya kearifan lokal di setiap daerah memiliki nilai-nilai yang arif dan positif yang mampu menyelesaikan permasalahan dalam masyarakat kaitannya dengan moral dan perilaku.

Melalui mata pelajaran sosiologi, peserta didik diarahkan untuk dapat menjadi warga negara Indonesia yang berbudi luhur dengan memegang nilai-nilai kearifan lokal, mencintai perbedaan budaya, serta mampu hidup berdampingan dan teratur dalam masyarakat. Pelajaran sosiologi di sekolah menengah atas memiliki tujuan agar siswa di sekolah mampu mengembangkan pengetahuan, pemahaman, dan kemampuan 
analisis terhadap kondisi sosial masyarakat agar ketika memasuki kehidupan bermasyarakat siswa sudah mampu untuk hidup berdampingan ditengah masyarakat yang dinamis. Mata pelajaran sosiologi di sekolah Juga disusun secara sistematis, komprehensif dan terpadu dengan mengintegrasikan konsep-konsep Ilmu Sosial sebagai sumber materi sosiologi sesuai dengan tema-tema kontekstual yang ada di masyarakat. Melalui pendekatan etnopedagogi peserta didik akan memperoleh pemahaman yang lebih luas dan mendalam dan mampu memaknai apa itu kearifan lokal.

\section{KESIMPULAN}

Indonesia merupakan negara multikultural. Namun karena globalisasi dan modernisasi kebudayaan-kebudayaan tersebut semakin tergeser eksistensinya. Oleh karena itu perlu ada revitalisasi dan upaya pelestarian terhadap budaya yang dimiliki masyarakat. Pergeseran budaya dan kearifan lokal yang terjadi saat ini merupakan tantangan bagi pemerintah dan dunia pendidikan untuk merevitalisasi nilai-nilai yang terkandung didalamnya, karena keduanya merupakan agen perubahan sosial dalam masyarakat dan Pendidikan dianggap sebagai alternatif yang bersifat preventif untuk membentuk generasi baru bangsa yang lebih baik. Institusi pendidikan memiliki peranan penting untuk mewujudkan pendidikan berbasis kearifan lokal. Kebijakan dan implementasi pendidikan yang berbasis karakter dengan mempertimbangkan berbagai nilai-nilai kearifan lokal ( local wisdom / genius) di sekolah menjadi sangat penting dan strategis dalam rangka membangun bangsa ini. Kearifan lokal dapat berfungsi sebagai salah satu sumber nilainilai yang luhur bagi tujuan tersebut.

Pendidikan berbasis kearifan lokal atau etnopedagogik dapat di implementasikan dalam mata pelajaran sosiologi dengan menyelipkan nilai- nilai kearifan lokal sebagai sumber belajar. Implementasi pendekatan etnopedagogi dalam pembelajaran sosiologi di sekolah menjadi salah satu upaya pemecahan persoalan-persoalan yang ada pada masyarakat. siswa diajak untuk peka terhadap lingkungan sosialnya. Siswa diajak untuk mencari tahu apa saja kearifan lokal yang ada pada daerahnya masing-masing. Karena pada dasarnya kearifan lokal di setiap daerah memiliki nilai-nilai yang arif dan positif yang mampu menyelesaikan permasalahan dalam masyarakat kaitannya dengan moral dan perilaku.

Untuk menjaga kearifan lokal dan nilai-nilai yang terkandung didalamnya harus dilakukan revitalisasi dan pelestarian oleh karena itu melalui pendidikan yang berbasis kearifan local diharapkan budaya-budaya lokal tetap terjaga eksistensinya. Sebagai seorang pendidik seharusnya guru memiliki wawasan yang luas mengenai budaya-budaya daerah sehingga akan lebih mudah untuk mengajak peserta didik mencintai dan melestarikan budayanya.

\section{FERENNSI}

Agung Hartoyo. 2012. "Eksplorasi Ayatrohaedi. 1986. Kepribadian Budaya Bangsa (Local Genius). Jakarta: Pustaka Pelajar.

Dasuki, H.A. (1977). Sejarah Indramayu. Indramayu: Depdikbud.

Dinas Pendidikan dan Kebudayaan Kabupaten Indramayu. (2004). Upacara Adat Ngarot. Indramayu: Depdikbud

Hartomo, H \& Amicum Aziz. (2010). Ilmu Sosial Dasar. Jakarta: Bumi Aksara.

Koentjaraningrat. (1976). Beberapa Pokok Antropologi Sosial. Djakarta: Dian Rakyat.

Koentjaraningrat. (2003). Pengantar Antropologi. Jakarta: Rineka Cipta.

Martono, N. (2012). Sosiologi Perubahan Sosial : Perspektif Klasik, Modern, Posmodern, dan Poskolonial. Jakarta: PT Raja Graffindo Persada.

Peursen, V. (1976). Sosiologi Kebudayaan. Jakarta: Kanisius.

Rahyono. (2009). Kearifan Budaya dalam Kata. Jakarta: Wedatamawidyasastra.

Rendra. (1983). Mempertimbangkan Tradisi. Jakarta: Gramedia.

Samian (Mantan Kuwu Lelea). (2005). Sejarah Desa Lelea. Indramayu: Tidak diterbitkan.

Sibarani, Robert 2012. Kearifan Lokal: Hakikat, Peran dan Metode Tradisi Lisan.

Jakarta: Asosiasi Tradisi Lisan.

Soekanto, S. (2010). Sosiologi : Suatu Pengantar. Jakarta: Rajawali Pers.

Sztompka, Piötr. (2008). Sosiologi Perubahan Sosial. Jakarta: Prenada. 